\title{
Recurrent Desmoplastic Small Round Cell Tumor
}

National Cancer Institute

\section{Source}

National Cancer Institute. Recurrent Desmoplastic Small Round Cell Tumor. NCI

Thesaurus. Code C158426.

The reemergence of desmoplastic small round cell tumor after a period of remission. 